\title{
A Duty Perspective on the Hate Speech Prohibition in the Equality Act
}

\section{P.E.R}

Pioneer in peer-reviewed, open access online law publications

Author

Maria E (Marelize) Marais

Affiliation

University of the Free State South Africa

Email maraisme@ufs.ac.za

Date Submission

17 November 2020

Date Revised

24 May 2021

Date Accepted

24 May 2021

Date published

21 June 2021

\section{Section Editor Mr M Laubscher}

How to cite this article

Marais ME "A Duty Perspective on the Hate Speech Prohibition in the Equality Act" PER / PELJ 2021(24) - DOI

http://dx.doi.org/10.17159/17273781/2021/v24i0a9236

Copyright

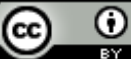

DOI

http://dx.doi.org/10.17159/1727-

3781/2021/v24i0a9236

\begin{abstract}
In November 2019 the Supreme Court of Appeal in Qwelane v South African Human Rights Commission ruled that section 10(1) of the Promotion of Equality and Prevention of Unfair Discrimination Act (Equality Act) 4 of 2000, otherwise known as the "hate speech" prohibition, was unconstitutional. The court said it was vague, overbroad and therefore unjustifiably infringing the right to freedom of expression. This contribution argues that every person's duty to respect others is central to the hate speech prohibition, and should therefore also be a central consideration in its interpretation. Related duties are those of the state to enact legislation and of courts to interpret and apply the law to promote the spirit, purport and objects of the Bill of Rights. References to relevant case law in various legal contexts provide the framework within which legal duties are examined in the context of unfair discrimination and, in particular, hate speech in terms of section 10(1) of the Equality Act. The constitutional obligations of the state, the courts and private persons to promote respect for the dignity of others are examined. The state's specific obligation in terms of section 9(4) of the Constitution of the Republic of South Africa, 1996 to enact legislation to prevent or prohibit unfair discrimination on the grounds listed in section 9(3) is reiterated. Finally, these duties are related to the section 10(1) prohibition in the Equality Act. Refuting the Supreme Court of Appeal's ruling in Qwelane, the reasonableness standard is applied to conclude that the prohibition gives due effect to the duties of the state and every person, and that the courts are duty-bound to interpret it accordingly.
\end{abstract}

\section{Keywords}

Hate speech; Equality Act; section 10; unfair discrimination; freedom of expression; duty, respect, dignity, reasonableness, hurt and harm; incitement; bona fide; conjunctive; Qwelane. 


\section{Introduction}

This contribution argues that, to the extent that section 10(1) of the Promotion of Equality and Prevention of Unfair Discrimination Act 4 of 2000 (the Equality Act) gives due effect to and functions within the boundaries of the constitutional duty not to discriminate unfairly related to group characteristics or, positively phrased, the duty to treat others with equal respect related to their group characteristics, it is unquestionably constitutionally compliant. The argument is supported by sections $7(1), 8(1)$ and 8(2) as well as in particular sections 9(3) and 9(4), interrelated with section 10, of the Constitution of the Republic of South Africa, 1996 (the Constitution).

In the interpretation of socioeconomic rights and the development of the common law, our courts have consistently employed the reasonableness standard when considering the duty to respect others, as well as the state's and the courts' related duties. For instance, in Loureiro v iMvula Quality Protection (Pty) Ltd (Loureiro), ${ }^{1}$ a delictual matter, the wrongfulness enquiry was stated to be based on the duty not to cause harm - indeed to respect rights - and questioned the reasonableness of imposing liability. ${ }^{2}$ The contribution therefore refers to relevant case law in various legal contexts when it explores and applies this standard in the context of unfair discrimination, in particular hate speech in terms of section 10(1) of the Equality Act. It illustrates and concludes that such an application on a caseby-case basis renders section 10(1) constitutionally compliant. It proceeds to demonstrate that the Supreme Court of Appeal in Qwelane $v$ South African Human Rights Commission ${ }^{3}$ in its interpretation of section 10(1) failed in its duty to promote the spirit, purports and objects of the Bill of Rights, failed to recognise the state's obligation in terms of section 9(4) of the Constitution to enact legislation to prohibit and prevent unfair discrimination on the grounds in section 9(3), and negated the duty of every person to respect others' human dignity.

The contribution is divided into six parts. This introduction concludes with a brief constitutional and legislative setting of section 10 of the Equality Act. The second part, with reference to relevant case law, discusses the

Maria E (Marelize) Marais. LLB (Stell) LLM (UFS) LLD (UFS). Research fellow, Free State Centre for Human Rights, University of the Free State, South Africa. E-mail: maraisme@ufs.ac.za. ORCiD ID: https://orcid.org/0000-0001-8633-8405. Loureiro v iMvula Quality Protection (Pty) Ltd 20143 SA 394 (CC). Loureiro v iMvula Quality Protection (Pty) Ltd 20143 SA 394 (CC) para 53. Qwelane v South African Human Rights Commission 20203 BCLR 334 (SCA). 
obligations of the state, human rights bodies, every person and the judiciary to promote respect for others in general, and in the context of unfair discrimination in particular. It appears that the scope of the duty to respect is generally achieved by applying the reasonableness standard to determine the wrongfulness of conduct alleged to have disadvantaged another on a case-by-case basis within the relevant framework of the Constitution. The next part assesses reasonableness review in various legal contexts. Part four considers whether section 10(1) of the Equality Act gives due effect to the obligation to prohibit and prevent unfair discrimination. This issue is addressed through a reasonableness assessment in the framework of the equality provisions of the Constitution and the Equality Act. A brief analysis of the disjunctive or conjunctive reading of section 10(1) of the Equality Act follows in part five, whereupon the article concludes with a discussion of the implications of its viewpoints for the Qwelane judgment in the Supreme Court of Appeal.

The following introductory constitutional and legislative setting of section 10 of the Equality Act serves to inform early references to section 10.

The Equality Act is transformative anti-discrimination legislation that addresses equality issues in accordance with the Constitutional Court's substantive approach. ${ }^{4}$ It aims to comply with the specific obligation in section 9(4) of the Constitution to enact national legislation to prevent or prohibit unfair discrimination based on the non-exhaustive list of protected grounds in section 9(3), not only by the state but also by private persons. It constitutes a "positive commitment progressively to eradicate socially constructed barriers to equality and to root out systemic or institutionalised under-privilege." ${ }^{5}$

The Equality Act distinctly reflects the objective of substantive equality. Its preamble states that

... systemic inequalities and unfair discrimination remain deeply embedded in social structures, practices and attitudes, undermining the aspirations of our constitutional democracy.

It then goes on to express a commitment to the facilitation of

... the transition to a democratic society, united in its diversity, marked by human relations that are caring and compassionate, and guided by the

\footnotetext{
4 See Klare 1998 SAJHR 146, 150 for a description of the concept "transformative constitutionalism".

5 See Pretorius 2010 SAJHR 545.
} 
principles of equality, fairness, equity, social progress, justice, human dignity and freedom. ${ }^{6}$

The Act does not criminalise conduct. Instead, its remedies are of a civil kind. It provides wide powers to courts, enabling the crafting of appropriate orders. ${ }^{7}$ Its objects include facilitating the "eradication" of and "overcoming" unfair discrimination, hate speech and harassment, and raising public awareness of the importance of promoting equality. ${ }^{8}$ It provides that the Equality Court may, during or after an inquiry, refer any proceedings before it to any relevant constitutional institution or appropriate body for mediation, conciliation or negotiation. ${ }^{9}$

Chapter 2 of the Act addresses the prevention, prohibition and elimination of unfair discrimination, hate speech and harassment. In addition to its general prohibition of unfair discrimination, ${ }^{10}$ the chapter specifies and prohibits particular forms of unfair discrimination, including separate prohibitions of unfair discrimination on specific stipulated grounds, ${ }^{11}$ the prohibition of harassment, ${ }^{12}$ the prohibition of the dissemination and publication of information that unfairly discriminates, ${ }^{13}$ and the prohibition of hate speech.

It should be noted that the Equality Act's structure of separate prohibitions does not exclude any of these forms of conduct from the ambit of unfair discrimination in terms of section 9(3) of the Constitution and the general prohibition of unfair discrimination in terms of section 6 of the Act. Neither does section 15 of the Act, which provides that sections 10 and 11 of the Act are not subject to fairness analysis in terms of section 14 of the Act, imply that hate speech and harassment are not forms of unfair discrimination. All the prohibited forms of conduct in the Equality Act differentiate in relation to the prohibited grounds in terms of section 9(3) of the Constitution, and all the Act's prohibitions were designed in compliance with the constitutional obligation to prohibit and prevent unfair

$6 \quad$ Albertyn and Fredman argue that "... substantive equality should be understood in terms of a four dimensional framework, which aims at addressing stigma, stereotyping, prejudice and violence; redressing socio-economic disadvantage; facilitating participation; and valuing and accommodating difference through structural change". See Albertyn and Fredman 2015 Acta Juridica 432.

7 Afriforum v Malema 20116 SA 240 (EqC) para 110.

8 Section 21(2) of the Promotion of Equality and Prevention of Unfair Discrimination Act 4 of 2000 (the Equality Act).

Section 21(4) of the Equality Act.

Section 6 of the Equality Act.

Sections 7-9 of the Equality Act.

Section 11 of the Equality Act.

Section 12 of the Equality Act. 
discrimination. It should therefore be apparent that fairness considerations are intrinsic to the hate speech and harassment prohibitions, entailing that a separate fairness review in terms of section 14 of the Act is not required. ${ }^{14}$ The term "hate speech" surely does not describe expression that discriminates fairly. Likewise "harassment" does not encompass fair sexual or other advances. In the words of Cooper, "(i)t is in the nature of the conduct that it can never be justified". ${ }^{15}$ In both instances the effects are systemic and indisputably detrimental, related to group characteristics. ${ }^{16}$

It is in this framework that section 10(1) of the Equality Act prohibits discriminatory speech (or "hate speech" as it is called in the section heading) in the following terms:

(1) Subject to the proviso in section 12, no person may publish, propagate, advocate or communicate words based on one or more of the prohibited grounds, against any person, that could reasonably be construed to demonstrate a clear intention to -
(a) be hurtful;
(b) be harmful or to incite harm;
(c) promote or propagate hatred.

Section 12, which contains a similar prohibition of the dissemination and publication of information that unfairly discriminates, then introduces the following proviso: ${ }^{17}$

Provided that bona fide engagement in artistic creativity, academic and scientific inquiry, fair and accurate reporting in the public interest or publication

14 See Marais and Pretorius 2015 PELJ 902-903; Marais and Pretorius 2019 PELJ 315. The articles maintain that hate speech is a form of unfair discrimination and that the most appropriate constitutional framework within s 10(1) should be interpreted and assessed is ss 9 and 10 of the Constitution.

15 See the following statement in Cooper 2002 ILJ 1: "As far as harassment is concerned, however, it is not possible to argue that it might be fair or justifiable as in constitutional (and labour) jurisprudence. It is in the nature of the conduct that it can never be justified." In Liberty Group Limited v M 201710 BLLR 991 (LAC) para 32 the Labour Appeal Court stated that "... (i)n treating harassment as a form of unfair discrimination in $s 6(3)$, the EEA recognises that such conduct poses a barrier to the achievement of substantive equality in the workplace by creating an arbitrary barrier to the full and equal enjoyment of an employee's rights, violating that person's dignity and limiting their right to equality at work".

16 Section 6 of the Equality Act requires proof of disadvantage as an element of discrimination as defined in terms of $s 1$ of the Act. On the systemic effects of harassment, see Fitzgerald 2017 Journal of Trauma and Dissociation. On the systemic effects of hate speech, see Gelber 2017 Constitutional Commentary 621623.

17 For an analysis of this proviso, see Marais and Pretorius 2019 PELJ 23-27. 
of any information, advertisement or notice in accordance with section 16 of the Constitution, is not precluded by this section.

Section 10(2), in turn, provides for hate speech that warrants criminal prosecution to be referred accordingly.

It is worth noting that the concepts "hurtful" and "harmful" in the hate speech prohibition seamlessly tie in with the constitutional commitment to healing, ${ }^{18}$ to attend to injury, and to facilitate the transition to a democratic society, "marked by human relations that are caring and compassionate". ${ }^{19}$

Even though the entire Act creates a regulatory structure to promote equality and prevent unfair discrimination, chapter 5 addresses the "(p)romotion of equality" separately and instructively. The chapter introduces and emphasises the duties, responsibilities and commitments of the state, the South African Human Rights Commission and other relevant constitutional institutions pertaining to the right to equality. Despite its evident design to meet the obligation in section 9(4) of the Constitution, chapter 5 of the Act has not as yet been enacted. This is probably because of a lack of capacity to properly assess and monitor compliance with the required equality plans and progress reports. ${ }^{20}$ The chapter nonetheless illuminates the content and scope of the duties and responsibilities that the Act seeks to uphold, and will therefore assist in the discussion.

\section{The obligations of the state, human rights bodies, every person and the judiciary to promote respect for others}

Fredman suggests that an understanding of what duties rather than different types of rights entail "gives us a more sophisticated tool for analysis and implementation". ${ }^{21}$ She argues that all rights give rise to a range of duties, including not only duties of constraint, but also duties to establish institutions, protect individuals from other individuals, and facilitate, promote and provide for people's needs and wants. ${ }^{22}$

Section 7(2) of the Constitution obligates the state to respect, protect, promote and fulfil the rights enshrined in the Bill of Rights. In addition, section 8(1) provides that the Bill of Rights applies to all law, and binds the legislature, the executive, the judiciary and all organs of state. In Governing

Preamble to the Constitution.

Preamble to the Equality Act.

See in this regard Kok et al Erasmus L Rev 54-55.

Fredman Human Rights Transformed 145.

Fredman Human Rights Transformed 10, 137. 
Body of the Juma Musjid Primary School v Essay ${ }^{23}$ (Juma Musjid), the Constitutional Court confirmed that section 8(1) imposed a positive obligation on the state with respect to all four components of section 7(2) of the Constitution. ${ }^{24}$ Section 8(2) provides that a provision of the Bill of Rights binds a natural or juristic person if and to the extent that, it is applicable, taking into account the nature of the right and the nature of any duty imposed by the right. ${ }^{25}$

As far as the right to equality is concerned, all these duties are particularised in terms of section 9(4) of the Constitution. The state must enact legislation to promote equality and prevent unfair discrimination by the state and every person. The definitions, stipulated objects, interpretative guidelines and detailed prohibitions of the Equality Act acknowledge and give effect to this explicit obligation. In addition, chapter 5 of the Act describes and reiterates the relevant duties, responsibilities and commitments of the state, the South African Human Rights Commission and other relevant constitutional institutions in this regard. Section 24 provides that the state and all persons have a "duty and responsibility" to promote and achieve equality. Section 27(1) refers to a "commitment" by all persons, bodies and institutions to the promotion of equality in their relationships with other bodies and in their public activities. Section $28(3)(a)$ reiterates that the state, institutions performing public functions and all persons have a "duty and responsibility" in particular to (i) eliminate discrimination on the grounds of race, gender and disability, and (ii) promote equality in respect of race, gender and disability. Carrying out this duty includes the adoption and introduction of legislative and other measures to (a) develop awareness of fundamental rights to promote a climate of understanding, mutual respect and equality; (b) develop and implement programmes to promote equality; and (c) where necessary or appropriate, develop action plans to address any unfair discrimination, hate speech or harassment. ${ }^{26}$

As stated above, section 8(1) of the Constitution binds the judiciary as well. Section 8(3) provides for the development of the common law to give effect

23 Governing Body of the Juma Musjid Primary School v Essay 20118 BCLR 761 (CC) (Juma Musjid).

$24 \quad$ Juma Musjid para 45.

25 See Bilchitz and Du Toit 2016 https://constitutionnet.org/sites/default/ files/chapter_3._fundamental_rights.pdf para 3.1.

26 Human rights bodies include the South African Human Rights Commission, the Commission for the Promotion and Protection of the Rights of Cultural, Religious and Linguistic Communities and the Commission for Gender Equality, established respectively in terms of ss 184, 185-186 and 187 of the Constitution. The Constitution tasks all these bodies with the protection, development, attainment and promotion of respect for human rights and a culture of human rights. 
to a right in the Bill of Rights, or to limit a right in accordance with section 36 of the Constitution, and section 173 states the inherent power of the Constitutional Court, the Supreme Court of Appeal and high courts to do so. Section 39(2) of the Constitution provides that every court, tribunal or forum must promote the spirit, purport and objects of the Bill of Rights, both when interpreting legislation and when developing the common or customary law.

Davis and Klare state that in giving effect to the Bill of Rights, it no longer suffices for courts passively to defer to the legislature. Courts are implicitly empowered and obligated to assess

... whether existing legislation (as filled out by the common law) adequately secures constitutional rights or is in need of a judicial jump-start. On occasion, it might be entirely legitimate and proper for a court to move out in front of the legislature. ${ }^{27}$

In Carmichele $v$ Minister of Safety and Security (Carmichele) ${ }^{28}$ the Constitutional Court described judges' duty in respect of both the civil and criminal law as to "remain vigilant" and "not hesitate to ensure that the common law is developed to reflect the spirit, purport and objects of the Bill of Rights ... whether or not parties in any particular case request the court to develop the common law under s 39(2)."29 The courts' commitment to this dynamic role manifests itself in various fields of law, as will be shown later. ${ }^{30}$

It is contended that in Qwelane v South African Human Rights Commission $(\text { Qwelane })^{31}$ the Supreme Court of Appeal in the interpretation of section 10(1) of the Equality Act neglected its duty to promote every person's constitutional responsibility to respect others - something that will be expanded on below.

The paragraphs that follow observe how the courts define and value the duty to respect others. Relevant case law includes cases in the context of the development of the common law in terms of sections 8(2), (3) and 39(2) of the Constitution, before the focus shifts to case law in the context of unfair discrimination, being the primary context of hate speech legislation. These cases will be revisited in part three of the contribution in the discussion of

\footnotetext{
Davis and Klare 2010 SAJHR 422.

Carmichele v Minister of Safety and Security 200110 BCLR 995 (CC) (Carmichele). Carmichele para 36.

In the discussion of the horizontal application of every person's duty to respect others, to be found under para 3 below.

31 Qwelane v South African Human Rights Commission 20203 BCLR 334 (SCA) (Qwelane) para 68.
} 
the nature and application of the reasonableness standard to determine the existence and scope of a duty to respect.

\title{
2.1 Case law considering the duty to respect others in the development of the common law
}

In Juma Musjid, the Constitutional Court addressed the application of sections $8(1)$ and $8(2)$ of the Constitution. The dispute was between the Juma Musjid Trust, which owned a private property where a school was situated, the Member for Education for KwaZulu-Natal, and the school governing body. A deadlock had arisen when the MEC failed to conclude an agreement with the trust setting out tenancy terms and conditions, as required by certain provisions of the South African Schools Act 84 of 1996. This culminated in a successful eviction claim by the trust in the high court. The court held that the MEC had a positive obligation to respect, protect, promote and fulfil the learners' right to a basic education, while there was no similar obligation on the trust. ${ }^{32}$ Yet the trust did have a negative constitutional obligation not to impair the learners' right to a basic education. In this regard the court stressed that

\begin{abstract}
... the purpose of section 8(2) of the Constitution is not to obstruct private autonomy or to impose on a private party the duties of the state in protecting the Bill of Rights, but rather to require private parties not to interfere with or diminish the enjoyment of a right. Its application also depends on the 'intensity of the constitutional right in question, coupled with the potential invasion of that right which could be occasioned by persons other than the State or organs of State'. ${ }^{33}$
\end{abstract}

This should not be understood to reduce private parties' duty to one of no positive responsibility. ${ }^{34}$ The Juma Musjid Trust was required to tolerate interference with its property rights until the learners' needs were met and the order was granted. ${ }^{35}$

Ultimately, the duty to respect the human rights of others may require various forms of action or restraint. This duty is encapsulated in the understanding of ubuntu in various spheres of law.

For instance, in $S \vee$ Makwanyane $^{36}$ (the death penalty case), the Constitutional Court acknowledged ubuntu as a constitutional value of

\footnotetext{
$32 \quad$ Juma Musjid para 57.

33 Juma Musjid paras 57-58.

$34 \quad$ Also see $A B$ v Pridwin Preparatory School 20205 SA 327 (CC) para 244.

35 Also see City of Johannesburg Metropolitan Municipality v Blue Moonlight Properties 39 (Pty) Ltd 20122 SA 104 (CC) para 40.

$36 \quad S$ v Makwanyane 19953 SA 391 (CC).
} 
fundamental importance for constitutional reasoning and the interpretation of entrenched fundamental human rights. Langa $\mathrm{J}$ stated that the rights to "unconditional respect, dignity, value and acceptance" from one's community also entailed the "corresponding duty to give the same respect, dignity, value and acceptance to each member of that community." ${ }^{37}$

Mokgoro $\mathrm{J}$ extended this view in Dikoko $v$ Mokhatla, ${ }^{38}$ stating that "a remedy based on the idea of ubuntu...could indeed give better appreciation and sensitise a defendant as to the hurtful impact of his or her unlawful actions, similar to the emerging idea of restorative justice in our sentencing laws." 39

Le Roux $v$ Dey ${ }^{40}$ sheds more light on the horizontal application of the constitutional duty to respect the dignity of others in the context of the common law of defamation. The applicants in the matter, then schoolchildren, had created and distributed a computer-generated image in which the face of the respondent, Dr Dey, then a deputy principal of the school, was superimposed alongside that of the school principal on an image of two naked men posing in a sexually suggestive way. ${ }^{41}$

The majority upheld the defamation claim, arguing that the reasonable observer would have evaluated the picture as intended to tarnish, in a humiliating and demeaning manner, Dr Dey's image and the respect that he enjoyed among the learners of the school. ${ }^{42}$ The majority argued that learners were not exempt from delictual liability, even for a "schoolboy prank". While the liability line is not clear-cut, it can be considered crossed

... when the joke becomes hurtful; when it represents the teacher as foolish, ridiculous and unworthy of respect. ${ }^{43}$

It was held that the applicants had crossed the line, and that the picture was defamatory. ${ }^{44}$

$37 \quad$ S v Makwanyane 19953 SA 391 (CC) para 224.

38 Dikoko $v$ Mokhatla 20071 BCLR 1 (CC). This matter dealt with the immunity from civil liability granted to municipal councillors in respect of their pronouncements when carrying out their duties.

39 Dikoko v Mokhatla 20071 BCLR 1 (CC) paras 68, 69.

$40 \quad$ Le Roux $v$ Dey 20116 BCLR 577 (CC).

$41 \quad$ Le Roux v Dey 20116 BCLR 577 (CC) paras 2-3.

$42 \quad$ Le Roux v Dey 20116 BCLR 577 (CC) paras 115-116.

$43 \quad$ Le Roux $v$ Dey 20116 BCLR 577 (CC) para 119.

$44 \quad$ Le Roux v Dey 20116 BCLR 577 (CC) paras 118-119. Also see paras 142, 154 and 202 respectively for the majority and minority judgments pertaining to separate claims for defamation and infringement of dignity based on the same facts. 
In Khumalo $v$ Holomisa (Khumalo), ${ }^{45}$ in turn, the issue was whether the law of defamation unjustifiably limited the right to freedom of expression as enshrined in section 16 of the Constitution by not requiring a plaintiff in a defamation action to plead that the defamatory statement is false in any circumstances. ${ }^{46}$ The applicants (members of the media) claimed that the common law should be developed under section 8(3) of the Constitution so as to allow them to comply with their duties as bearers of the constitutional right to freedom of expression. Considering the intensity of the right to freedom of expression, the court concluded that the right to freedom of expression in casu was of direct horizontal application, as contemplated by section 8(2) of the Constitution. The court acknowledged the important obligation of the media in a democratic society to provide citizens with both information and a platform for the exchange of ideas. ${ }^{47}$ However, the court was satisfied that the defence of reasonable publication provided for

... publishing such material when it is reasonable to do so and while acting with due care and respect for the individual interest in human dignity. ${ }^{48}$

The recent recognition in Komape $v$ Minister of Basic Education ${ }^{49}$ of shock, grief and insult as substantiating psychological harm in the law of delict signifies the level of empathy that our Constitution requires of the state, every person, and the judiciary. On 20 January 2014 five-year-old Michael Komape drowned in a pit latrine at his school in Limpopo. The high court dismissed a claim for emotional shock and grief on the basis that the requirement for such claims, namely psychiatric injury, had not been proved. The Supreme Court of Appeal later overturned this decision, awarding damages for emotional shock and grief to each member of the Komape family, to a total value of $R 1,4$ million.

The court confirmed the requirement that delictual liability could follow only if there had been a psychiatric lesion. However, it reiterated that our common law of delict was flexible and in many cases broad enough to provide all the appropriate relief for a breach of a constitutional right, depending on the circumstances of each particular case..$^{50}$ Ultimately the court accepted symptoms of depression and posttraumatic stress disorder - "suffered as a result of the emotional trauma the appellants had undergone and embracing the grief they had experienced" - as constituting

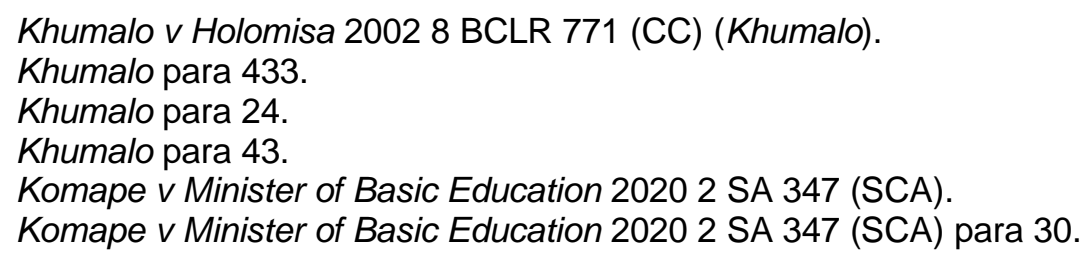


such psychiatric injury. ${ }^{51}$ It was further taken into account that the claimants' mental agony had been exacerbated by their feelings of insult due to the lack of support received from the provincial and national education authorities. $^{52}$

Parties' bargaining autonomy and certainty of contract are paramount principles in contract law. Yet Hutchinson contends that South African statutes to protect weaker parties in order to promote social justice under a banner of "transformative constitutionalism" have been enacted in many areas of contracting. ${ }^{53}$

Moreover the Constitutional Court has moved away from formalism to a more substantive approach to adjudication. ${ }^{54}$ In Everfresh Market Virginia (Pty) Ltd $v$ Shoprite Checkers (Pty) Ltd (Everfresh) ${ }^{55}$, for instance, the applicants requested that the common law of contract governing agreements-to-agree be developed in terms of section 39(2) of the Constitution so that parties who undertake to negotiate a new rent for a renewed lease would be required to do so reasonably and in good faith. ${ }^{56}$ (Historically, the South African law of contract has maintained that all contracts are based on an underlying requirement of good faith as a standard akin to honesty or rationality, though not independently actionable. ${ }^{57}$ ) The Court rejected the contention that the concept of good faith was too vague to be enforceable, stating that the law of contract, infused with constitutional values, including values of ubuntu, requires negotiation to be done "reasonably, with a view to reaching an agreement and in good faith". ${ }^{58}$ However, the application was dismissed on the basis

$51 \quad$ Komape $v$ Minister of Basic Education 20202 SA 347 (SCA) para 34.

52 Komape $v$ Minister of Basic Education 20202 SA 347 (SCA) para 55.

$53 \quad$ Hutchinson 2019 Journal of Commonwealth Law 267.

$54 \quad$ Hutchinson 2019 Journal of Commonwealth Law 233.

55 Everfresh Market Virginia (Pty) Ltd v Shoprite Checkers (Pty) Ltd 20123 BCLR 219 (CC) (Everfresh).

56 Bhana and Broeders 2014 THRHR 166-168.

57 See Hutchinson 2019 Journal of Commonwealth Law 229 fn. 182, where the author cites examples of good faith as a standard akin to honesty or rationality. See the analysis of comparative jurisprudence on the role of good faith in the legal frameworks of civil law jurisdictions in Beadica 231 CC v Trustees for the time being of the Oregon Trust 20209 BCLR 1098 (CC) paras 61-70.

58 Everfresh paras 71-72. See also paras 22-24, 36. See Bhana and Broeders 2014 THRHR 175, where Bhana and Broeders argue that the value of good faith as informed by ubuntu should take better account of the lived realities and values of the people of South Africa. Also see Hutchinson 2019 Journal of Commonwealth Law 257-258, where Hutchinson considers the approach that the "indigenous value of fair dealing, captured by the vernacular term 'ubuntu'" in contract law, should be given content "with regard to the context of the parties' own business dealings, rather than with reference to an exogenous standard." 
that Everfresh had failed to raise its constitutional argument before the high court and Supreme Court of Appeal. ${ }^{59}$

In Beadica 231 CC $v$ Trustees for the time being of the Oregon Trust (Beadica) $^{60}$ the applicants had failed to give written notice of their intentions to renew their leases within the notice period, as required in terms of the renewal clause. They requested renewals or new lease agreements a few weeks later. Some months went by without further communication, after which the first respondent demanded that the applicants vacate the leased premises. ${ }^{61}$ The applicants, who had acquired their businesses in terms of a black economic empowerment initiative funded by the National Empowerment Fund (the Fund), contended that the strict enforcement of the renewal clause of the lease agreements would be contrary to public policy, as it would bring an end to their franchise agreements, and lead to the failure of a black economic empowerment initiative. ${ }^{62}$

The majority judgment held that it is only when a contractual term or its enforcement is contrary to public policy that a court may refuse to enforce it. ${ }^{63}$ In giving effect to the spirit, purport and objects of the Bill of Rights as required by section 39(2) of the Constitution and in honouring the transformative mandate of the Constitution, the public policy analysis considers values of fairness, reasonableness, justice and ubuntu. These values also underlie and inform the substantive law of contract. The requirement that contracts are to be performed in good faith, for instance, implies a duty not to commit anticipatory breach, and the principle of reciprocity was relaxed on the grounds of fairness where a party to a reciprocal contract had used the other party's partial performance. ${ }^{64}$ The majority judgment emphasised that protection of the sanctity of contracts is essential to the achievement of the constitutional vision of our society. ${ }^{65}$ Courts must therefore exercise perceptive restraint when considering the invalidation of or refusal to enforce contractual terms. ${ }^{66}$ On the other hand,

59 See Bhana and Broeders 2014 THRHR 170-171, where Bhana and Broeders hold the view that the constitutional argument should have been considered ex mero motu. They contend that Everfresh illustrates how the traditional "highly structured, technicist, literal and rule bound" operation of procedural law in post-apartheid South Africa still tends to sidestep the Constitution.

Beadica 231 CC v Trustees for the time being of the Oregon Trust 20209 BCLR 1098 (CC) (Beadica).

Beadica para 7.

Beadica para 10.

Beadica paras 71-72.

Beadica paras 73-77.

Beadica para 85.

Beadica para 88. 
courts should not shrink from their constitutional duty to infuse public policy with constitutional values. ${ }^{67}$ Where a number of constitutional rights and values are implicated, a careful balancing exercise is required to determine whether the enforcement of the contractual terms would be contrary to public policy in the circumstances. ${ }^{68}$

The majority found that it was fatal to the applicants' case that they had not adequately explained why they had not complied with the terms that they sought to avoid. The equality argument was rejected on the basis that a finding for the applicants could deter parties from electing to contract with beneficiaries of the Fund, having the effect of undermining the very objects that the Fund and section 9(2) of the Constitution seek to achieve. ${ }^{69}$

In a dissenting judgment Froneman $\mathrm{J}$ acknowledged that the first judgment "sets the regulation of fairness in our contract law squarely and unambiguously within the ambit of our constitutional value system." He wrote separately to give further guidance as to how to translate the objective constitutional values that were recognised by the first judgment into practical application. He also reached a different outcome on application to the facts. ${ }^{70}$

In his application to the facts, Froneman $\mathrm{J}$ accepted the applicants' assertion of relative lack of sophistication as an explanation for their non-compliance with the strict notice requirement. Considering the disproportionate unfairness between their conduct and that of the first respondent and their prejudice in losing their businesses against that of the first respondent, who loses nothing, he would uphold the appeal.

\subsection{Case law considering the duty to respect others in the context of unfair discrimination}

The following statements from case law consider the duty to respect others in the context of section 9 of the Constitution and legislation aimed at the promotion of equality. 
In accordance with the substantive approach to equality, the Constitutional Court has acknowledged impact as the "determining factor" in establishing unfairness. ${ }^{71}$ In Van Heerden, Moseneke $\mathrm{J}$ stated the following:

In the assessment of fairness or otherwise a flexible but 'situation-sensitive' approach is indispensable because of shifting patterns of hurtful discrimination and stereotypical response in our evolving democratic society. ${ }^{72}$

Some non-discrimination duties, in particular the duty of reasonable accommodation, are expressly positive. In this regard Pretorius, Klinck and Ngwena contend that reasonable accommodation ${ }^{73}$

$\ldots$ is a principle that is aimed at promoting a model of equality that recognises diversity, disadvantage, and the legitimacy of compensatory and distributive justice.

This principle was endorsed in MEC for Education: KwaZulu-Natal v Pillay (Pillay), ${ }^{74}$ where the Constitutional Court made it clear that nondiscrimination might require positive action in the form of reasonable accommodation. ${ }^{75}$

The following dictum in Hoffmann $v$ South African Airways demonstrates the same approach: ${ }^{76}$

\begin{abstract}
People who are living with HIV must be treated with compassion and understanding. We must show ubuntu towards them. They must not be condemned to 'economic death' by the denial of equal opportunity in employment. This is particularly true in our country, where the incidence of HIV infection is said to be disturbingly high. ${ }^{77}$
\end{abstract}

From all of the cases above, it would seem that the duty to respect others requires all persons in their interaction with one another to be mindful not to inflict or reinforce suffering related to violations of human dignity and, where appropriate, to make sacrifices and positive contributions so as to accommodate diversity. As illustrated above, notions such as compassion, care, harm, hurt, good faith and respect all have relevance in the context of respect for others in various fields of law. Surely they are particularly

$71 \quad$ Harksen $v$ Lane 199711 BCLR 1489 (CC) para 51 sets out various factors to be cumulatively considered to determine whether a discriminatory provision or conduct has had an unfair impact on complainants.

$72 \quad$ Minister of Finance $v$ Van Heerden 200412 BLLR 1181 (CC) para 27.

73 Pretorius, Klinck and Ngwena "Reasonable Accommodation" para 7.2.

74 MEC for Education: KwaZulu-Natal v Pillay 20082 BCLR 99 (CC) (Pillay). Also see Standard Bank of South Africa $v$ The Commission for Conciliation, Mediation and Arbitration 20084 BLLR 356 (LC) para 79.

$75 \quad$ Pillay para 64.

$76 \quad$ Hoffmann $v$ South African Airways 200012 BLLR 1365 (CC).

77 Hoffmann $v$ South African Airways 200012 BLLR 1365 (CC) para 38. 
relevant in legislation such as the Equality Act. In isolation these notions are broad. That is why the scope of the duty to respect needs to be determined on a case-by-case basis in the framework of the Constitution. This is generally achieved by applying the reasonableness standard to determine the wrongfulness of conduct alleged to have disadvantaged another.

\section{The reasonableness standard}

Reasonableness in the context of wrongfulness is not so much concerned with the reasonableness of the defendant's conduct as with the reasonableness of imposing liability on the defendant for the harm resulting from such conduct. ${ }^{78}$ As Van der Westhuizen J said in Loureiro: ${ }^{79}$

\section{The wrongfulness enquiry focuses on the conduct and goes to whether the policy and legal convictions of the community, constitutionally understood, regard it as acceptable. It is based on the duty not to cause harm - indeed to respect rights - and questions the reasonableness of imposing liability.}

Quinot and Liebenberg describe reasonableness review in the context of the adjudication of socioeconomic rights as "a normative and contextsensitive standard", the norm being "the overall objective to ensure the realisation of the relevant socio-economic rights." ${ }^{80}$ In the same context and in line with this understanding, Young contends that the present operation of reasonableness review in South African law provides for "incremental, and context-driven" inquiry. ${ }^{81}$ She distinguishes this "holistic" enquiry, which incorporates "notions of necessity, suitability and proportionality in an ad hoc method" from the "disciplined, regimented, structured justification inquiry into the aims, necessity, (sometimes suitability) and proportionality of a limitation of a right." 82 Young contends that it is even possible for the context-driven articulations of reasonableness to link the standard of review to the remedy. This is the case, for example, in doctrines such as "meaningful engagement" in jurisprudence on the right to housing. The absence of meaningful engagement between the parties before an eviction may point to the unreasonableness of government policy. But so too can meaningful engagement be prescribed as a remedy, thus linking the two analyses in ways that may not be as immediately obvious in a proportionality

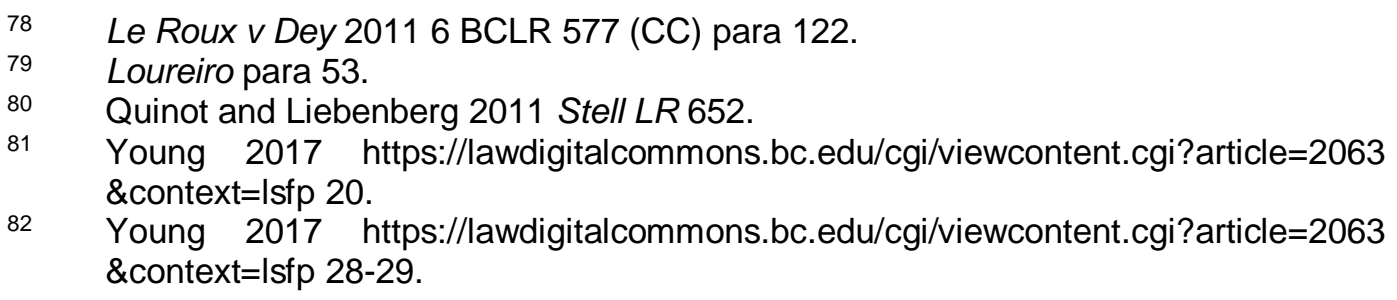


analysis. ${ }^{83}$ This Young calls a "proportionality-inflected" reasonableness standard. ${ }^{84}$

The intrinsic proportionality exercise is evident in Government of the Republic of South Africa $v$ Grootboom, ${ }^{85}$ where the Constitutional Court held that "everyone must be treated with care and concern", and that measures failing "to respond to the needs of those most desperate" might not pass the reasonableness test. ${ }^{86}$

In Carmichele, in the context of a vicarious liability delictual claim based on neglect of duty, the applicant sued the ministers concerned for damages, having suffered a brutal attack by a man who was awaiting trial for attempted rape. Despite the man's history of sexual violence, the police and prosecutor had recommended his release without bail. In the Constitutional Court the primary issue was whether, in the light of the state's constitutional duties, particularly the duty to safeguard the rights of women, the concept of "wrongfulness" in the law of delict should be broadened under section 39(2) of the Constitution so as to cover the conduct of the police and prosecutor.

The court confirmed the pre-constitutional reasonableness test to determine the wrongfulness of omissions. This test requires the careful weighing of the interests of the parties inter se as well as the conflicting interests of the community in order to determine "society's notions of what justice demands". ${ }^{87}$ The court held, however, that in applying this test the courts a quo had overlooked the demands of section 39(2) of the Constitution. The proportionality exercise now requires that

$\ldots$ the relevant factors must be weighed in the context of a constitutional state founded on dignity, equality and freedom and in which government has positive duties to promote and uphold such values. ${ }^{88}$

In Carmichele relevant considerations included the stipulated constitutional functions and duties of the police; the fact that sexual violence was "the single greatest threat to the self-determination of South African women"; the courts' duty to protect the equality, dignity and freedom of all women and send a clear message to the accused as well as to other potential rapists

\footnotetext{
83 Young 2017 https://lawdigitalcommons.bc.edu/cgi/viewcontent.cgi?article=2063 \&context=Isfp 21-22.

84 Young $2017 \mathrm{https}: / /$ lawdigitalcommons.bc.edu/cgi/viewcontent.cgi?article=2063 \&context=Isfp 29-30. Government of the Republic of South Africa v Grootboom 200011 BCLR 1169 (CC) para 44.

$87 \quad$ Carmichele para 42.

$88 \quad$ Carmichele para 43.
} 
and to the community; the pressures under which prosecutors work, especially in the magistrate's courts; caution not to use hindsight as a basis for unfair criticism, which could have a chilling effect on prosecutors' exercise of their judgment in favour of the liberty of the individual; and South Africa's duty under international law to prohibit all gender-based discrimination and to take reasonable and appropriate measures to prevent the violation of women's rights. ${ }^{89}$

Let us now revisit the cases cited in the discussion of the obligation to respect others, but now with the focus on reasonableness assessment.

In Juma Musjid the Constitutional Court commenced its analysis with an assessment of the reasonableness of the trust's action in seeking an order for eviction. In this regard the court considered the nature of the trust's duty, considering that the primary obligation in respect of the learners' right to a basic education belonged to the state. The trust's obligation was secondary, having arisen only from its willingness to allow the property to be used as a public school, and to enter into an agreement in terms of the Schools Act. ${ }^{90}$

In Le Roux $v$ Dey the relevant remarks were made obiter but are nonetheless enlightening. As in Carmichele the court argued that in the law of delict

(a) the criterion of wrongfulness ultimately depends on a judicial determination of whether - assuming all the other elements of delictual liability to be present - it would be reasonable to impose liability on a defendant for the damages flowing from specific conduct; and (b) that the judicial determination of that reasonableness would in turn depend on considerations of public and legal policy in accordance with constitutional norms. ${ }^{91}$

Brand AJ reiterated that courts could in appropriate circumstances recognise new or adapt existing grounds to give effect to legal policy and constitutional norms. ${ }^{92}$ He stated that it would be irresponsible to allow the extension of the reasonable publication defence contended for by the Freedom of Expression Institute without properly investigating the potential repercussions. Such investigation would require a balancing of the freedom of expression of schoolchildren on the one hand and the dignity of teachers - including their reputation - on the other. Relevant considerations were that satire was part of the functioning of democracy, and that children should be allowed to experiment with it. The effect of such experimentation also

\footnotetext{
$89 \quad$ Carmichele para 62.

90 Juma Musjid para 62

$91 \quad$ Le Roux v Dey 20116 BCLR 577 (CC) paras 120-128.

92

Le Roux v Dey 20116 BCLR 577 (CC) para 123.
} 
needed to be explored. Of further relevance was the growing tendency in schools to challenge the status and authority of teachers, with a concomitant breakdown in discipline, which remained an essential requirement for a functioning school system. ${ }^{93}$

In Khumalo the Constitutional Court stated that the standard of reasonableness served as a "tool" to affirm the constitutional value of human dignity, which concerned both an individual's sense of self-worth and the worth of human beings in our society. At the same time, it gave recognition to the role that the Constitution accorded free speech and expression. In the court's view, the defence of reasonable publication avoided a winner-takes-all result and established a proper balance between freedom of expression and the value of human dignity. It encouraged editors and journalists to act with due care and respect for the individual interest in human dignity prior to publishing defamatory material, without precluding them from publishing such material when it is reasonable to do so. ${ }^{94}$

In Beadica Froneman $\mathrm{J}$ concluded that freedom of contract and good faith are complementary principles of our law of contract. In his view

(t)his means that the individualism of our law of contract is one that takes account of the reasonable expectation of the parties to the contract as well as that of the wider community. ${ }^{95}$

Before Pillay is discussed, it needs to be stressed - as did the court in that matter - that "(i)t would ... be wrong to reduce the test for fairness to a test for reasonable accommodation."96 Yet section 14(3) of the Equality Act includes, as one of the considerations in determining fairness, the extent to which a respondent has taken steps to accommodate diversity. ${ }^{97}$ The current focus, therefore, is on determining the scope of the duty to reasonably accommodate, in particular the boundary of undue hardship. In Pillay Langa CJ said that the difficult question

... is not whether positive steps must be taken, but how far the community must be required to go to enable those outside the 'mainstream' to swim freely in its waters. ${ }^{98}$

Le Roux v Dey 20116 BCLR 577 (CC) para 128.

Khumalo para 43.

Beadica para 177. Also see para 16. Also see Barkhuizen v Napier 20077 BCLR 691 (CC) para 28.

$96 \quad$ Pillay para 77.

$97 \quad$ Pillay para 77.

$98 \quad$ Pillay para 76. 
Pillay concerned the wearing of a nose stud to school by learner Sunali Pillay. The factors considered in the reasonableness assessment in Pillay reflect the Constitutional Court's sensitivity to the diverse real-life commitment to identity values, and the individual hurt and social harm that may result from violations of these values. On the balancing scale were the importance of the practice of wearing a nose stud to Sunali, on the one hand, and the hardship that permitting her to wear the stud would cause the school on the other..$^{99}$ The symbolic effect of denying Sunali the right to wear it for even a short period would have signalled that her religion and culture were not welcome, ${ }^{100}$ while marginalising religions and cultures was utterly inconsistent with the values of the Constitution. Instead, the court argued that allowing Sunali to wear the stud would not have any demonstrable effect on school discipline or the standard of education, while it would pose the benefit of integrating learners with diverse cultures. ${ }^{101}$ Lastly, the court stressed that while neither the Equality Act nor the Constitution required identical treatment, they did require equal concern and equal respect. ${ }^{102}$

In conclusion, the duty to respect others is of extreme pertinence to the consideration of equality and dignity claims, as well as the interpretation and application of prohibitions of equality and dignity infringements. The Constitution explicitly requires the prohibition and prevention of unfair discrimination. Thus, to the extent that section 10(1) functions within the reasonable boundaries of this duty, it is unquestionably constitutionally compliant. To any extent that it may exceed these boundaries, its constitutionality will need to be determined in terms of section 36 of the Constitution. Considering that the reasonableness assessment to determine the scope of the relevant duty does consider the impact of the limitation of freedom of expression, a section 36 analysis is unlikely to produce a different outcome. ${ }^{103}$

\section{Section 10(1) of the Equality Act}

Section 10(1) of the Equality Act prohibits discriminatory expression in compliance with the explicit constitutional obligation in section 9(4) of the Constitution to prohibit and prevent unfair discrimination on the grounds described in section 9(3). Moreover, one should not overlook the fact that

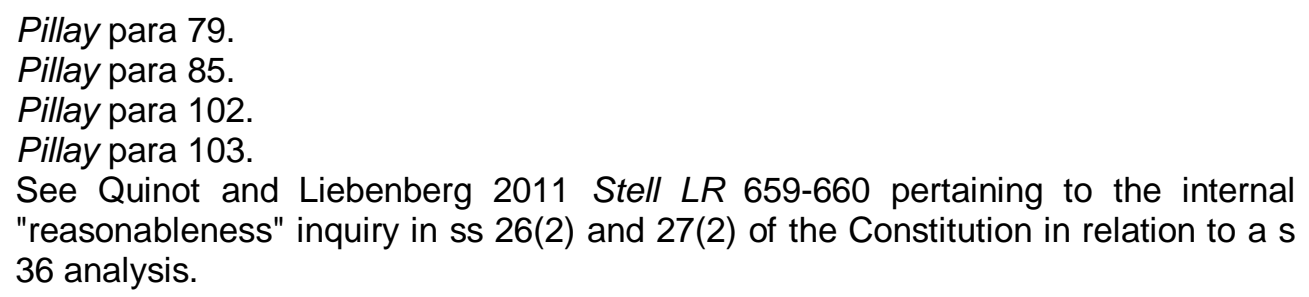


the prevention of unfair discrimination also extends to conduct that reinforces or promotes a culture of systemic inequality, where disempowerment, marginalisation and exclusion based on group characteristics undermine the constitutional project of transformation. Gelber goes so far as to view expression with harmful effects as including

... that others were persuaded of negative stereotypes, a conditioning of the environment such that racism was normalized, subordination, silencing, fear, victimization, emotional symptoms, restrictions on freedom, lowering of selfesteem, maintenance of social imbalances of power, and undermining of their dignity. ${ }^{104}$

The proviso in section 12 of the Act clarifies the ambit of section 10(1). It explicitly excludes bona fide engagement in the forms of expression it describes. The particular activities it describes clearly relate to the protected forms of expression listed in section 16(1) of the Constitution. The engagement is to be "in accordance with section 16 of the Constitution". This implies that unprotected expression under section 16(2) of the Constitution, as well as comparably serious criminalised expression, is not excluded from the ambit of the prohibition. ${ }^{105}$ This kind of expression should be referred for possible criminal prosecution and, as far as appropriate and feasible, be dealt with under the Equality Act. Primarily section 10(1) is concerned with engagement in expression protected under section 16(1) of the Constitution that is not bona fide, but intended to hurt or harm others, or to promote or incite hatred, on one or more of the prohibited grounds in section $9(3)$ of the Constitution. ${ }^{106}$

The relevant question is whether the section 10 prohibition gives due effect to the obligation to prevent unfair discrimination. It should be taken into account that while hate speech may marginalise and silence target groups, free expression may serve to promote equality and human dignity, expose systemic unfair discrimination, and condemn discriminatory practices. The Constitutional Court in South African National Defence Union v Minister of Defence ${ }^{107}$ argued that free expression was "at the heart" of a democracy and formed part of a "web of mutually supporting rights" in the Constitution, including freedom of religion, belief and opinion, the right to dignity, to freedom of association, to vote and to stand for public office, and to

\footnotetext{
104 Gelber 2017 Constitutional Commentary 623.

105 Marais and Pretorius 2015 PELJ 912.

106 Marais and Pretorius 2015 PELJ 928.

107 South African National Defence Union v Minister of Defence 19965 BCLR 609 (CC) para 7.
} 
assembly. ${ }^{108}$ It stands to reason, therefore, that any restriction of freedom of constitutionally protected expression should be carefully scrutinised in the light of the Constitution.

The following analysis substantiates that section 10(1) indeed incorporates the fairness and justification considerations of section 14 of the Equality Act.

Section 14(2), read with section 14(3), requires the following factors to be considered:

(2) In determining whether the respondent has proved that the discrimination is fair, the following must be taken into account:
(a) The context;
(b) the factors referred to in subsection (3);
(c) whether the discrimination reasonably and justifiably differentiates between persons according to objectively determinable criteria, intrinsic to the activity concerned.

(3) The factors referred to in subsection (2)(b) include the following:

(a) Whether the discrimination impairs or is likely to impair human dignity;

(b) the impact or likely impact of the discrimination on the complainant;

(c) the position of the complainant in society and whether he or she suffers from patterns of disadvantage or belongs to a group that suffers from such patterns of disadvantage;

(d) the nature and extent of the discrimination;

(e) whether the discrimination is systemic in nature;

(f) whether the discrimination has a legitimate purpose;

(g) whether and to what extent the discrimination achieves its purpose;

(h) whether there are less restrictive and less disadvantageous means to achieve the purpose;

(i) whether and to what extent the respondent has taken such steps as being reasonable in the circumstances to -

\footnotetext{
108 South African National Defence Union v Minister of Defence 19965 BCLR 609 (CC) paras 7-8. Also see Case v Minister of Safety and Security; Curtis v Minister of Safety and Security 19965 BCLR 609 (CC) para 27.
} 
(i) address the disadvantage which arises from or is related to one or more of the prohibited grounds; or

(ii) accommodate diversity.

Section 10(1) requires the demonstration of a clear intention, reasonably construed, to have the effects described in the prohibition. ${ }^{109}$ Determining how a reasonable person would construe such an intention would necessarily involve a contextual consideration of both broad social and incident-specific considerations, including the nature and extent of the past and ongoing suffering of the relevant target group. It would need to take account of the relative positions and powers of the speaker and the target group, as well as the potential for hurt, harm or the promotion or incitement of hatred. Overall, these considerations resemble the factors listed in section 14(2)(a) and 14(3) of the Act.

Determining bona fides in terms of the section 12 proviso invokes the same consideration that is articulated in section 14(2)(c) of the Act, namely whether the disputed expression reasonably and justifiably differentiates according to objectively determinable criteria intrinsic to the activity concerned, regardless of whether the expression might hurt or harm, promote or incite hatred. ${ }^{110}$

It is worth noting that the determination of the intention to hurt or harm or promote or incite hatred has to be "clear". If it is reasonable to accept that the speaker bona fide engaged in any of the forms of expression described in the proviso, even if hurt or harm ensued or the expression promoted or propagated hatred, it would not constitute hate speech as contemplated by section 10(1). In addition the expression has to be aimed at (an)other person(s). In this regard the Supreme Court of Canada in Saskatchewan (Human Rights Commission) $v$ Whatcott stated that hate speech legislation "does not target the ideas, but their mode of expression in public and the effect that this mode of expression may have."111

The argument is that section 10(1) provides for a case-by-case interpretation by the courts in accordance with section 39(2) of the Constitution, promoting the spirit, purport and objects of the Bill of Rights. It

109 The malicious intent required by the prohibition stands in contrast to the bona fide qualification in the proviso. The attributes of malice in the law of defamation are reflected in The Citizen 1978 (Pty) Ltd v McBride 20118 BCLR 816 (CC) paras 104105.

110 Bhana and Broeders 2014 THRHR 166-168; Hutchinson 2019 Journal of Commonwealth Law 229 fn. 182. Also see fn. 57 above.

111 Saskatchewan (Human Rights Commission) v Whatcott 20131 SCR 467 para 51. 
calls on our courts to distinguish the legitimate expression of opinions on controversial matters, such as same-sex marriage, from low-value, degrading speech that does a disservice to the constitutional protection of the right to freedom of expression. It calls on our courts to be alert to a construal of a contested expression that could rebut the inference that the required intention was present. It calls on our courts to interpret the bona fide requirement when dealing with hate speech complaints. It specifically calls on our courts to interpret the fairness, accuracy and public interest qualifications when dealing with reporting. It provides for vulnerabilities in society, as well as levels of healing and reconciliation, to be taken into account. It requires courts to outline the duty of members of society to be mindful of others' vulnerabilities. It provides remedies designed to facilitate ubuntu, and to contribute to the healing of our convalescent society and its members. ${ }^{112}$ It also provides that the Equality Court may at any stage of the proceedings refer the matter before it to a relevant constitutional institution or appropriate body for mediation, conciliation or negotiation. ${ }^{113}$ This discretion should be judicially exercised. ${ }^{114}$ With regard to extreme hate speech that falls under section 16(2)(c) of the Constitution and is explicitly excluded from the ambit of the proviso, section 10(2) read with section 21(2)(n) mandates the Equality Court to identify verbal onslaughts that threaten our democracy. These should be referred to the Director of Public Prosecutions having jurisdiction for the institution of criminal proceedings in terms of the common law or relevant legislation.

A duty-based reasonableness standard, as held in Carmichele, considers

.. whether the defendant ought reasonably and practically to have prevented
harm to the plaintiff: in other words, is it reasonable to expect of the defendant
to have taken positive measures to prevent the harm. ${ }^{115}$

The enquiry is "holistic", "proportionality-inflected", "incremental, and context-driven", as alluded to earlier. ${ }^{116}$ Applying this standard to section 10 will consider that the prohibition holds people liable for low-value expression ${ }^{117}$ clearly intended to degrade others because of their group identity, or to promote or incite such degradation. The prohibited expression is unessential for the bona fide communication of constitutionally protected opinions or information, including controversial opinions and information on

Section 21 of the Equality Act.

Section 21(4)(b) of the Equality Act.

Marais 2019 JJS 116.

Carmichele para 42.

See para 4 above.

See De Reuck v Director of Public Prosecutions (Witwatersrand Local Division) 2003 12 BCLR 1333 (CC) para 59. 
sensitive issues relating to group characteristics. Remedies designed to facilitate transformation are available, as are mediation options. This indicates that, as far as the duties of the state and every person are concerned, the prohibition is indeed reasonable. The duty of the courts is to interpret the section accordingly.

In the light of the intrinsic fairness and justification considerations relevant to the reasonableness analysis, it is contended that no further argument is necessary to establish that the prohibition's limitation of the right to freedom of expression complies with section 36 of the Constitution.

Next, views on whether the prohibition should be read disjunctively or conjunctively are briefly shared. The contribution then concludes with the implications of the arguments that it has raised for the Qwelane judgment in the Supreme Court of Appeal.

\section{A disjunctive or conjunctive reading of section 10(1)}

In the analysis above, section 10(1) was read disjunctively. It has been argued that a conjunctive reading would narrow down the prohibition, rendering it constitutionally compliant. ${ }^{118}$ However, it is submitted that a conjunctive reading of section 10(1) would unduly narrow down the prohibition in the light of the state's obligation in terms of section 9(4) of the Constitution to prohibit and prevent unfair discrimination against anyone.

The Oxford English Dictionary defines the adjective "conjunctive" as "(r)elating to or forming a connection or combination of things" and "(i)nvolving the combination or co-occurrence of two or more conditions or properties". The Cambridge Dictionary defines "disjunctive" as "lacking any clear connection" and "expressing a choice between two or more things, where only one is possible". ${ }^{119}$ An extended definition of "disjunctive" provided by the Merriam Webster Online Dictionary defines the term as "relating to, being, or forming a logical disjunction", "expressing an alternative or opposition between the meanings of the words connected", and "expressed by mutually exclusive alternatives joined by or". ${ }^{120}$ The

\footnotetext{
118 See Human Rights Commission v Qwelane; Qwelane v Minister for Justice and Correctional Services 20182 SA 149 (GJ) para 60; South African Human Rights Commission v Khumalo 20191 SA 289 (GJ) para 82.

119 Cambridge Dictionary 2020 https://dictionary.cambridge.org/dictionary/english/ disjunctive.

120 Merriam Webster 2020 https://www.merriam-webster.com/dictionary/disjunctive.
} 
same dictionary further distinguishes between "exclusive" and "inclusive" disjunction. "Exclusive disjunction" is defined as

a compound proposition in logic that is true when one and only one of its constituent statements is true. ${ }^{121}$

"Inclusive disjunction", in turn, is defined as

a complex sentence in logic that is true when either or both of its constituent propositions are true. ${ }^{122}$

The conjunction "and/or" reflects this latter meaning.

An inclusive disjunctive reading would best enable the courts to interpret section 10 of the Equality Act to give due effect to section 9(3) and (4) of the Constitution. This contention is based on the implications should either of the other readings (exclusive disjunctive and conjunctive) be adopted.

Hate speech can evidently be hurtful and harmful, and incite harm, and promote and propagate hatred, or various combinations of these, all at the same time. An exclusive disjunctive reading would therefore clearly not make sense.

A conjunctive reading of section 10(1) means that in order to constitute hate speech, the relevant intention must at once be to hurt and to harm or incite harm and to promote or propagate hatred. ${ }^{123}$ Textually, a conjunctive reading is feasible, despite the alternatives in section 10(1)(b) and (c). Section 10(1) would then cover speech that is hurtful and harmful and promotes hatred; speech that is hurtful, incites harm and propagates hatred; speech that is hurtful, incites harm and promotes hatred; as well as speech that is hurtful, harmful and propagates hatred. The direct implication of this reading, however, is that expression directed at an audience comprising only members of the target group would not qualify as hate speech under section 10(1). After all, speech directed at members of the target group would neither promote nor propagate hatred of their own group. This cannot be what the lawmakers had in mind with the prohibition of unfair discrimination "against anyone" in terms of section 9(4). As has appeared from quotes in this contribution, the terms "hurt" or "hurtful" are employed

\footnotetext{
121 Merriam Webster 2020 https://www.merriam-webster.com/dictionary/exclusive\%20 disjunction.

122 Merriam Webster 2020 https://www.merriam-webster.com/dictionary/inclusive\%20 disjunction.

123 SAHRC 2019 https://www.sahrc.org.za/home/21/files/SAHRC\%20Finding\% 20Julius\%20Malema\%20\&\%20Other\%20March\%202019.pdf para 4.2.1.
} 
by the courts in various contexts. ${ }^{124}$ The explicit inclusion of "hurt" in section $10(1)$ (a) suggests that the very experience of humiliation or degradation is considered to constitute the disadvantage required in the Act's definition of unfair discrimination. No further proof of consequential harm is required.

An inclusive disjunctive reading would allow a case-by-case consideration of the effects, impact and blameworthiness of the relevant speech. This kind of reading is submitted to be what the lawmakers intended. It clearly and emphatically speaks to the immediate hurt, as well as to the long-term personal and social harm of humiliation and degradation based on group characteristics. It allows for nuanced findings, which could then be related to the most appropriate remedies.

\section{The interim order of the Supreme Court of Appeal in Qwelane}

In Qwelane the Supreme Court of Appeal held that section 10(1) of the Equality Act was overbroad and vague to the extent that it could not be saved by an interpretive exercise. According to the court, "the standard set in s 10(1) of PEPUDA [i.e. the Equality Act] in relation to the constitutional standard provided by $s$ 16(2)(c)" was "barely intelligible". ${ }^{125}$ The court afforded Parliament 18 months to remedy the constitutional defect. It went on to order that, during these 18 months, section 10(1) would read as follows: ${ }^{126}$

No person may advocate hatred that is based on race, ethnicity, gender, religion or sexual orientation and that constitutes incitement to cause harm.

Apart from adding sexual orientation as a ground, this interim regulation is formulated in the terms of section 16(2)(c) of the Constitution, which categorically excludes certain forms of hate speech from constitutional protection.

The court's findings were the result of its erroneous employment of section 16(2)(c) as the normative framework for evaluating the hate speech provision of the Equality Act. As contended, while expression under section 16(2)(c) falls within the boundaries of section 10(1) of the Equality Act, the correct framework for the interpretation of section 10(1) is in fact section

\footnotetext{
124 Dikoko v Mokhatla 20071 BCLR 1 (CC) paras 68, 69 (fn. 39 above); Le Roux v Dey 20116 BCLR 577 (CC) para 119 (fn. 43 above); Minister of Finance $v$ Van Heerden 200412 BLLR 1181 (CC) para 27 (fn. 72 above).

125 Qwelane paras 68, 76.

126 Section 10(2) of the Equality Act was adjusted correspondingly.
} 
9(4) of the Constitution, which requires the prohibition and prevention of unfair discrimination. Expression that unfairly discriminates is obviously not limited to expression under section 16(2)(c) of the Constitution.

The court's finding of vagueness was inter alia based on the "difficulty of determining what 'hurtful' in s 10(1)(a) of PEPUDA was meant to capture". ${ }^{127}$ Although the court did find that "hurtful" was concerned with a person's subjective emotions and feelings in response to the actions of a third party, it held that this did not "equate with causing harm or incitement to harm". Moreover, the court found the meaning of the proviso in part "difficult to discern". ${ }^{128}$ This contribution's understanding of these aspects has been stated above.

The ultimate concern is the non-compliance of the court's interim order with the obligation in section 9(4) of the Constitution. Apart from the grounds that it itself lists, the court disregards the prohibited grounds stipulated in section 9(3). By essentially requiring incitement, the interim order clearly excludes the direct infliction of harm, related to their group characteristics, on members of a target group. As alluded to above, members of a target group can hardly be incited to harm their own group. Moreover, using the phrasing of Sachs $\mathrm{J}$ in National Coalition for Gay and Lesbian Equality $v$ Minister of Justice, ${ }^{129}$ where he discussed the focus on dignity as the guarantor of substantive equality, ${ }^{130}$ the Equality Act is transformative legislation following "a situation-sensitive human rights approach" focussing on "the lives as lived and the injuries as experienced by different groups in our society", addressing "the injury to dignity imposed upon people as a consequence of their belonging to certain groups." By restrictively relating the "hate speech" prohibition in the context of the Equality Act to section 16(2)(c) of the Constitution, the court not only unduly disregards its duty to uphold section 9(4) of the Constitution, it also downplays the threat of the anti-democratic expression that falls within the narrow ambit of section 16(2) of the Constitution. This kind of hate speech enjoys no constitutional protection and calls for robust legislative and other measures, including criminalisation, to combat the serious threat of incitement. This is why

\footnotetext{
$127 \quad$ Qwelane para 68.

128 Qwelane para 76.

129 National Coalition for Gay and Lesbian Equality v Minister of Justice 199812 BCLR 1517 (CC).

$130 \quad$ National Coalition for Gay and Lesbian Equality $v$ Minister of Justice 199812 BCLR 1517 (CC) para 126.
} 
section 10(2) of the Equality Act provides for the referral of this type of hate speech for criminal prosecution. ${ }^{131}$

Far from denying the legislator the right to prohibit hate speech in a clearly defined and properly limited provision exceeding the narrow hate speech provision of the Constitution, the court ended its judgment with the following words: ${ }^{132}$

We should be allowed to be firm in our convictions and to differ on the basis of conscience. What we are not free to do is to infringe the rights of others and we certainly are not free to inflict physical or psychological harm on others.

Yet in its interpretation of section 10(1) of the Equality Act it failed in its duty to promote the spirit, purport and objects of the Bill of Rights. It failed to recognise the state's obligation in terms of section 9(4) of the Constitution to enact legislation to prohibit and prevent unfair discrimination on the grounds in section 9(3). And it negated the duty of every person to respect others' human dignity, in particular related to their group identity.

\section{Conclusion}

In S v Makwanyane, the following statements were made: ${ }^{133}$

The postamble to the Constitution gives expression to the new ethos of the nation by a commitment to 'open a new chapter in the history of our country', by lamenting the transgressions of 'human rights' and 'humanitarian principles' in the past, and articulating a 'need for understanding, but not for vengeance, a need for reparation but not retaliation, a need for ubuntu but not for victimization'.

This is the law of our country. It cannot be ignored, especially not when interpreting legislation designed to promote substantive equality in compliance with an explicit constitutional requirement to do so. Section 10(1) of the Equality Act holds people to this commitment. This contribution argues that it does so reasonably in accordance with the legal convictions of society, as embodied in the Constitution. It can and should be interpreted to promote the spirit, purport and objects of the Bill of Rights, which include freedom of expression. Section 10(1) does not prevent the communication of controversial views or ideas, but prohibits expression from being used as a tool to hurt or harm others, or to promote or incite hatred, based on group characteristics. It disallows homophobic utterances such as those of Qwelane, through which "he gave vent to his bigotry, was strident,

Marais and Pretorius 2019 PELJ 15-17.

Qwelane para 95.

S v Makwanyane 19953 SA 391 (CC) para 263. 
provocative and unapologetic about it", as described in the court's judgment. ${ }^{134}$ Ultimately, it empowers the vulnerable to participate in the social discourse. Narrowing down the hate speech prohibition in the Equality Act so that discriminatory expression on any prohibited ground similar to Qwelane's expressions is tolerated in our transformative society would not only negate but also violate the constitutional commitment to its foundational values.

\section{Bibliography}

\section{Literature}

Albertyn and Fredman 2015 Acta Juridica

Albertyn $C$ and Fredman $S$ "Equality beyond Dignity: Multi-Dimensional Equality and Justice Langa's Judgments: Part III: Reflections on Themes in Justice Langa's Judgments" 2015 Acta Juridica 430-455

Bhana and Broeders 2014 THRHR

Bhana D and Broeders N "Agreements to Agree: Everfresh Market Virginia (Pty) Ltd v Shoprite Checkers (Pty) Ltd 20121 SA 256 (CC)" 2014 THRHR 164-176

Cooper 2002 ILJ

Cooper C "Harassment on the Basis of Sex and Gender: A Form of Unfair Discrimination" 2002 ILJ 1-44

Davis and Klare 2010 SAJHR

Davis DM and Klare K "Transformative Constitutionalism and the Common and Customary Law" 2010 SAJHR 403-509

Fitzgerald 2017 Journal of Trauma and Dissociation

Fitzgerald LF "Still the Last Great Open Secret: Sexual Harassment as Systemic Trauma" 2017 Journal of Trauma and Dissociation 483-489

Fredman Human Rights Transformed

Fredman S Human Rights Transformed: Positive Rights and Positive Duties (Oxford University Press New York 2008)

Gelber 2017 Constitutional Commentary

Gelber K "Hate Speech: Definitions and Empirical Evidence" 2017 Constitutional Commentary 619-662

$134 \quad$ Qwelane para 76. 
Hutchinson 2019 Journal of Commonwealth Law

Hutchinson A "Good Faith in Contract: A Uniquely South African Perspective" 2019 Journal of Commonwealth Law 227-271

Klare 1998 SAJHR

Klare KE "Legal Culture and Transformative Constitutionalism" 1998 SAJHR 146-188

Kok et al 2020 Erasmus $L$ Rev

Kok A et al "The Promotion of Equality and Prevention of Unfair Discrimination Act 4 of 2000: Proposals for Legislative Reform to Promote Equality through Schools and the Education System" 2020 Erasmus L Rev 49-64

Marais 2019 JJS

Marais ME "Hate Speech in Context: Commentary on the Judgments of the Equality Court and the Supreme Court of Appeal in the Masuku Dispute" 2019 JJS 101-118

Marais and Pretorius 2015 PELJ

Marais ME and Pretorius JL "A Contextual Analysis of the Hate Speech Provisions of the Equality Act" 2015 PELJ 901-941

Marais and Pretorius 2019 PELJ

Marais ME and Pretorius JL "The Constitutionality of the Prohibition of Hate Speech in terms of Section 10(1) of the Equality Act: A Reply to Botha and Govindjee" 2019 PELJ 1-37

Pretorius 2010 SAJHR

Pretorius JL "Fairness in Transformation: A Critique of the Constitutional Court's Affirmative Action Jurisprudence" 2010 SAJHR 536-570

Pretorius, Klinck and Ngwena "Reasonable Accommodation"

Pretorius JL, Klinck ME and Ngwena CA "Reasonable Accommodation" in Pretorius JL, Klinck ME and Ngwena CA (eds) Employment Equity Law (LexisNexis Butterworths Durban 2012) ch 7

Quinot and Liebenberg 2011 Stell LR

Quinot $G$ and Liebenberg S "Narrowing the Band: Reasonableness Review in Administrative Justice and Socio-Economic Rights Jurisprudence in South Africa" 2011 Stell LR 639-663 


\section{Case law}

AB v Pridwin Preparatory School 20205 SA 327 (CC)

Afriforum v Malema 20116 SA 240 (EqC)

Barkhuizen v Napier 20077 BCLR 691 (CC)

Beadica 231 CC v Trustees for the time being of the Oregon Trust 20209 BCLR 1098 (CC)

Carmichele v Minister of Safety and Security 200110 BCLR 995 (CC)

Case $v$ Minister of Safety and Security; Curtis $v$ Minister of Safety and Security 19965 BCLR 609 (CC)

City of Johannesburg Metropolitan Municipality v Blue Moonlight Properties 39 (Pty) Ltd 20122 SA 104 (CC)

De Reuck v Director of Public Prosecutions (Witwatersrand Local Division) 200312 BCLR 1333 (CC)

Dikoko v Mokhatla 20071 BCLR 1 (CC)

Everfresh Market Virginia (Pty) Ltd v Shoprite Checkers (Pty) Ltd 20123 BCLR 219 (CC)

Governing Body of the Juma Musjid Primary School v Essay 20118 BCLR 761 (CC)

Government of the Republic of South Africa v Grootboom 200011 BCLR 1169 (CC)

Harksen $v$ Lane 199711 BCLR 1489 (CC)

Hoffmann v South African Airways 200012 BLLR 1365 (CC)

Human Rights Commission v Qwelane; Qwelane v Minister for Justice and Correctional Services 20182 SA 149 (GJ)

Komape $v$ Minister of Basic Education 20202 SA 347 (SCA)

Khumalo v Holomisa 20028 BCLR 771 (CC)

Le Roux v Dey 20116 BCLR 577 (CC) 
Liberty Group Limited v M 201710 BLLR 991 (LAC)

Loureiro v iMvula Quality Protection (Pty) Ltd 20143 SA 394 (CC)

MEC for Education: KwaZulu-Natal v Pillay 20082 BCLR 99 (CC)

Minister of Finance $v$ Van Heerden 200412 BLLR 1181 (CC)

National Coalition for Gay and Lesbian Equality v Minister of Justice 1998 12 BCLR 1517 (CC)

Qwelane v South African Human Rights Commission 20203 BCLR 334 (SCA)

S v Makwanyane 19953 SA 391 (CC)

Saskatchewan (Human Rights Commission) v Whatcott 20131 SCR 467

South African Human Rights Commission v Khumalo 20191 SA 289 (GJ)

South African National Defence Union v Minister of Defence 19965 BCLR 609 (CC)

Standard Bank of South Africa $v$ The Commission for Conciliation, Mediation and Arbitration 20084 BLLR 356 (LC)

The Citizen 1978 (Pty) Ltd v McBride 20118 BCLR 816 (CC)

\section{Legislation}

Constitution of the Republic of South Africa, 1996

Promotion of Equality and Prevention of Unfair Discrimination Act 4 of 2000

South African Schools Act 84 of 1996

\section{Internet sources}

Bilchitz and Du Toit 2016 https://constitutionnet.org/sites/default/files/ chapter_3._fundamental_rights.pdf

Bilchitz D and Du Toit L 2016 Assessing the Performance of South Africa's Constitution - Chapter 3: Fundamental Rights in South Africa's Constitution https://constitutionnet.org/sites/default/files/chapter_3._fundamental_rights .pdf accessed 16 November 2020 
Cambridge Dictionary 2020 https://dictionary.cambridge.org/dictionary/ english/disjunctive

Cambridge Dictionary 2020 Disjunctive https://dictionary.cambridge.org/ dictionary/english/disjunctive accessed 16 November 2020

Merriam Webster 2020 https://www.merriam-webster.com/dictionary/ disjunctive

Merriam Webster 2020 Disjunctive https://www.merriamwebster.com/dictionary/disjunctive 16 November 2020

Merriam Webster 2020 https://www.merriam-webster.com/dictionary/ exclusive\%20disjunction

Merriam Webster 2020 Exclusive Disjunction https://www.merriamwebster.com/dictionary/exclusive\%20disjunction 16 November 2020

Merriam Webster 2020 https://www.merriam-webster.com/dictionary/ inclusive\%20disjunction

Merriam Webster 2020 Inclusive Disjunction https://www.merriamwebster.com/dictionary/inclusive\%20disjunction 16 November 2020

SAHRC 2019 https://www.sahrc.org.za/home/21/files/SAHRC\% 20Finding\%20Julius\%20Malema\%20\&\%20Other\%20March\%202019.pdf South African Human Rights Commission 2019 Findings of the South African Human Rights Commission Regarding Certain Statements Made by Mr Julius Malema and Another Member of the Economic Freedom Fighters https://www.sahrc.org.za/home/21/files/SAHRC\%20Finding\%20Julius\%20 Malema\%20\&\%20Other\%20March\%202019.pdf accessed 16 November 2020

Young 2017 https://lawdigitalcommons.bc.edu/cgi/viewcontent.cgi?article= 2063\&context=Isfp

Young KG 2017 Proportionality, Reasonableness, and Economic and Social Rights https://lawdigitalcommons.bc.edu/cgi/viewcontent.cgi?article $=2063 \&$ context=Isfp accessed 12 May 2021

\section{List of Abbreviations}

$\begin{array}{ll}\text { Erasmus L Rev } & \text { Erasmus Law Review } \\ \text { ILJ } & \text { Industrial Law Journal } \\ \text { JJS } & \text { Journal for Juridical Science } \\ \text { PELJ } & \text { Potchefstroom Electronic Law Journal } \\ \text { SAHRC } & \text { South African Human Rights Commission }\end{array}$


SAJHR

Stell LR

THRHR
South African Journal on Human Rights Stellenbosch Law Review Tydskrif vir Hedendaagse Romeins-Hollandse Reg / Journal of Contemporary Roman-Dutch Law 